\title{
Die völkerrechtliche Lehre des Weltkrieges
}

\author{
Von \\ Walther Schücking \\ Professor der Rechte in Marburg \\ Associé de l'Institut de droit international \\ Korrespondierendes Mitglied des amerik. Instifufs für Völkerrecht
}

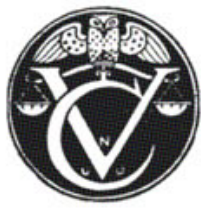

Leipzig $\backsim$ Verlag von Veit \& Comp. 1918

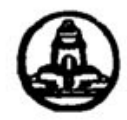


Alle Rechte, einschließlich de Uborsetzungsrechts, vorbehelten.

Druck von Metzger \& Wittig in Loiprig. 


\section{Jonkheer Dr. B. de Jong van Beek en Donk Ministerialrat im holländischen Justizıninisterium}

Generalsekretär der Zentralorganisation für einen dauernden Frieden in Freundschaft zugeeignet. 
